\title{
Grzegorz Madrjas
}

mgr inż.

Kierownik Działu Strategii Rozwoju Systemu Tramwajowego, Tramwaje Warszawskie Sp. z o.o. gmadrjas@tw.waw.pl

DOI: 10.35117/A_ENG_16_07_02

\section{Construction of a Light Rail line to Wilanów}

\begin{abstract}
The paper describes main design ideas for a project of a tramway connection between districts of Warsaw: Wola, Ochota, Mokotów and Wilanów. Historical aspects, main spatial documents as well as feasibility studies are also discussed. Moreover, key design challenges are presented which concern routing options and limitations of passing through special locations.
\end{abstract}

Keywords: LRT; Light rail; Warsaw Tramways; Preemption; Wilanów

\section{Historical view}

Tram route to Wilanow has already been built in Warsaw twice: in 1937, was put into operation extended to the broad-gauge tram route Czerniakowa, which after the war was not rebuilt, and in 1957 - normal-track, whose liquidation was already sixteen years later.

Both routes lead to Wilanow from downtown from streets Czerniakowska - Powsińska Wiertnicza, but they differed with a place to overcome the Warsaw escarpment: prewar tram ran down the street Książęca, thus post-war - Gagarina and Spacerowa (as indeed compatible with the popular Warsaw urban legend which was about to contribute to its liquidation). It should be also mentioned that the tram leaving the street Książęca turn on a route running along Traktat Królewski from the street Bagatela until street Miodowa [3] - and then it was the most important route in the capital. In this context, arguments about the alleged "incompatibility" of trams on the Krakowskie Przedmieście or Nowy Świat with their historical character sound extremely original.

At least since the late nineties it is said about the restoration of tram connection in this direction, but using - to varying degrees - Sobieski Street corridor, along which were built high buildings Stegien and Sadyba. In the last decade, this street was extended to Wilanów Town - a modern urban concept, which will constitute - at least in stages - the target waypoint.

Construction of the route to Wilanow was analyzed in the "functional analysis - motor variants of the transport system in Warsaw with a particular focus on rail transport," from 1999, as a branch of the rapid tram route Bemowo - the Western Station - Siekierki - Gocław. This route would lead through the streets of Górczewska - Prymasa Tysiaclecia - Battle of Warsaw 1920 - Banacha - Rakowiecka - Goworka - Spacerowa - Gagarin - a new bridge over the Vistula River - Fieldorfa - Bor-Komorowski to loop in Gocław. The branch to Wilanow and ran to the node at the intersection Gagarina / Czerniakowska Streets Czerniakowska Witosa Avenue, Sobieski Avenue, Wilanowska Avenue to Wilanow loop, although in the end it was suggested to consider the recommendations of the route in Belwederska Street - which shorten the way to downtown [9]. 


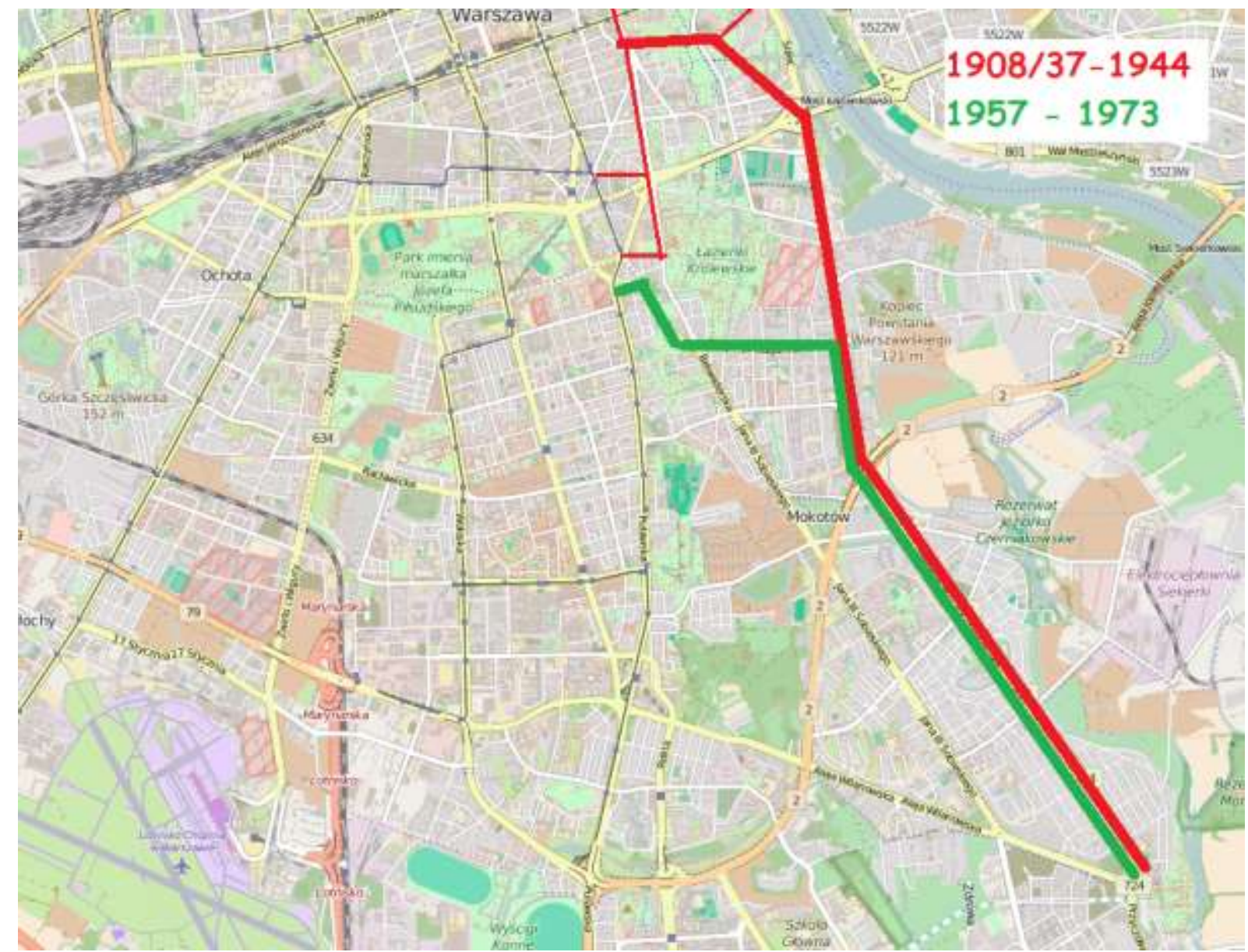

1. The historical course of routes to Wilanow (ed. own work based on [3] and [4] )

Subsequent documents are a set of Feasibility Studies: Study for the route Banach Wilanow [8] from 2004, based on which were created in 2006 development of routes for Western Station - Wilanow and Siekierki (planned for the Warsaw Technology Park). These documents included admittedly recommendation,which refers to straighten the routes in the Lower Mokotów, but at the same time abandoned the analysis of both the connection to the Wola (Górczewska Street and Rondo Siberian Deportees in the meantime have been upgraded without providing reserves for the tram route), and so on Gocław.

Very promising results of this study work, both in terms of the number of expected passengers (in the year when it started: more than 5,000 people in the center of the top of the morning on the street Gagarina, strong bidirectional stream between Mokotów and Ochota by Mokotów Field row 6,000 people in cross-section) and analysis socio - economic (eIRR = $13 \%$ for the route Siekierki [6] and $14.4 \%$ for the route Western station - Wilanow [7]) confirmed the validity of the implementation of the route and contributed to its entry to the adopted in 2006 Study of Conditions and Directions of Development Spatial Capital City Warsaw [5]. The course coincides with option recommended in the Feasibility Study, and for branches on the Siekierki was only clarified on Gagarin Street - further extension was only signaled. 


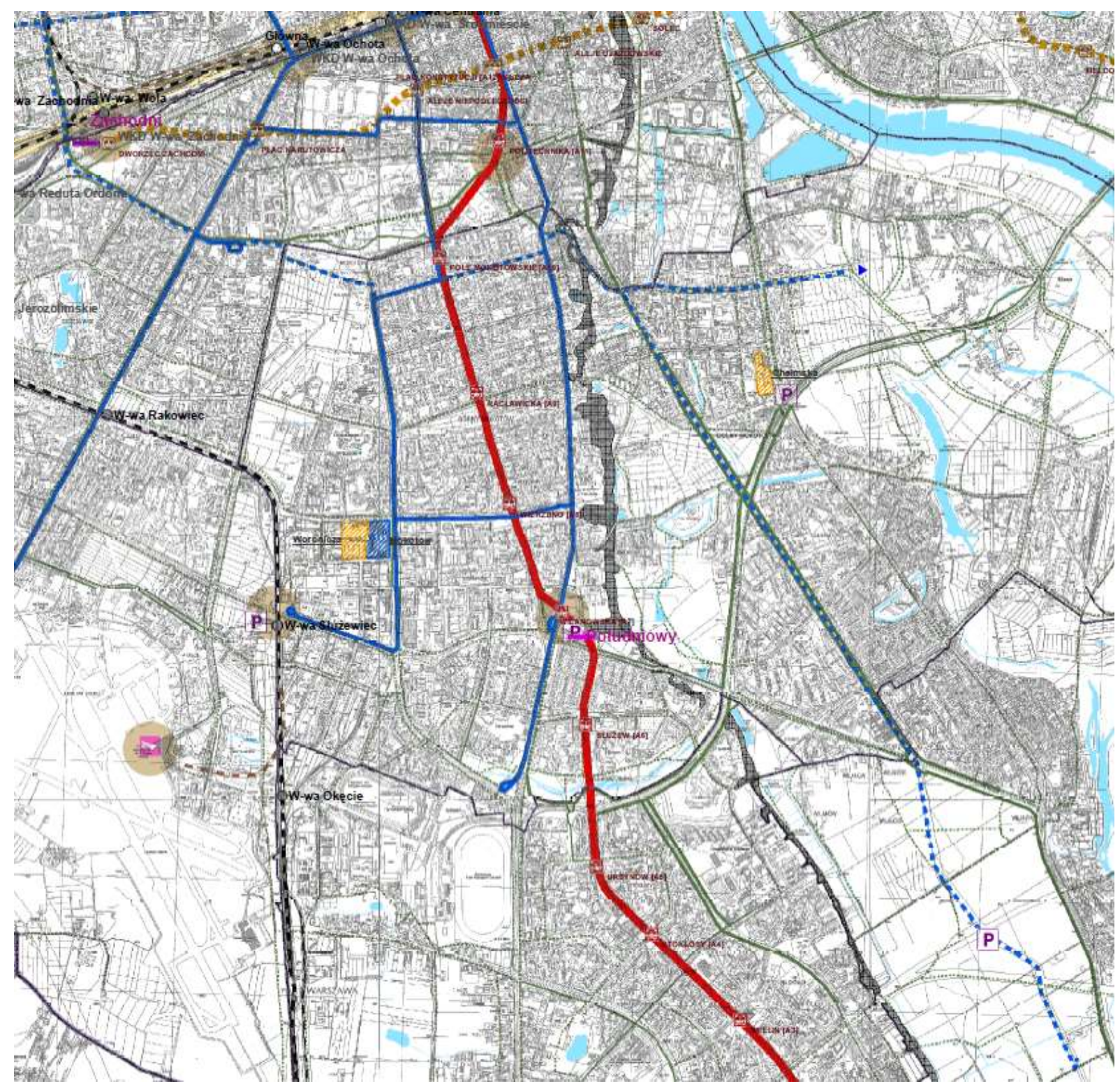

2. Route to Wilanow in Warsaw SUiKZP (excerpt from [7])

Since then the Warsaw trams began efforts to enter this route for longstanding "Implementing Agreement" setting out the framework and conditions for cooperation from the Capital City Warsaw in the development and operation of the Warsaw tram - a record is necessary for the commencement of such a complex and expensive investment - or other proof of willingness to implement the route, which would open the preparatory work. In the meantime, however, the legitimacy conducting the investment was once again confirmed in the "Functional analysis - motor variants of the transport system in Warsaw with particular emphasis on rail transport" from 2013 [1].

The decision about building the route was announced by the authorities in Warsaw in mid-2015 with the announcement of the list of projects to be implemented in the EU budget 2014-2020. On this list were, among others, task "Construction of the tram route to Wilanow with the purchase of rolling stock and associated infrastructure", including the construction of the route from the West Railway Station to Wilanow (no section of the Field Mokotowskie provided for the implementation of the own funds), the construction of a tram depot R5 on Annopol and the purchase of 50 trams bidirectional to use this route. 


\section{Route construction assumptions}

Assumptions for the construction based upon the recommendation of the documents-study and experience gained by the Warsaw tram company during intensive modernization program which ran from 2007-2013; They were in the tender specifications for the planning and development concept, based on which will result in an environmental decision for investments, as well as design a permanent organization of traffic.

The area covered by the concept is broader than the scope of the EU project; it encompasses a route from Kasprzak Street - and so back to the concept of connection with wolska tram network and branch routes: along Gagarin Street and potentially - in the street. St. Boniface to the current bus station Stegny. There was also provideed the possibility of alternative route (in the area of West Railway Station and Odolany also when passing through the Upper Mokotów and Mokotów Field), although a basic course in principle has been established at the stage of study work.

The planned route will be a hybrid of typical solutions for fast tram and the modern city tram. This will therefore run entirely separated from general traffic - except for intersections and a short section of track tram-bus, it is also envisaged the possibility of overcoming selected sections in a manner separated from the traffic level route (i.e. a tunnel), whereby before the end of the study works foregone conclusion is the only region of the West railway Station, where you need to go under the diametrical railway line. At crossings that are overcome conflictual it is assumed the tram priority, whereby contractor will be responsible in principle for developing coordination signaling; adaptive slutions are prepared by Warsaw Trams. Applied solutions will allow to achieve high-speed communication - the order of 24$26 \mathrm{~km} / \mathrm{h}$ on the whole route - which would bracket it to fast tram class. It is worth mentioning that such a parameter meet the two recently opened tram routes in Warsaw within Silesian Insurgents Street in Bemowo and along North Bridge and Światowida Street in Tarchomin.

Design solutions involve the construction of a two-track routes with a high proportion of the tracks slab buildings grass adapted to the speed of $60 \mathrm{~km} / \mathrm{h}$ and on selected sections of up to $70 \mathrm{~km} / \mathrm{h}$. Allowed to use longitudinal gradients up to 5\% (and exceptionally up to 6\%), although the passage along the Vistula embankment street Spacerowa does not require quite as large declines. All the stops will be equipped with platforms connected to the ground level ramp, bus shelters, passenger information displays. The platforms will allow simultaneous operation of two trams a length of $33 \mathrm{~m}$ each. It is preliminary estimated the need to build 4 new traction substations and the upgrading of 2 or 3 existing.

The route will be normally not provided with loops, with the exception of Stegien area where it is considered to use the current loop bus; it would allow targeting to Lower Mokotów also one-way rolling stock, which still accounts for almost $90 \%$ of the fleet tram in Warsaw. Ultimately, it is assumed the creation of a loop in Wilanow and Siekierki (respectively in the area of street Rosnowski and the CHP Siekierki), however deadline of end sections of routes is currently unknown, and they are not in the scope of the EU project. In case of the western end of the route, the realization of the connection of the Kasprzak Street will be possible to the marginal trams on both the near loop Wolski cemetery, and on some remote settlement Górczewska or Koło. Here should be added that to produce such an important connection between districts will undoubtedly change the behavior of passengers and also the existing tram network, hence can be expected, e.g. a referral by the West Railway district lines operated by one-way fleet from Wola or Zoliborz to Mokotow or Włochy.

For the needs of operation of the route it is expected to purchase 55 bi-directional trams (of which 50 are included in the scope of the EU project) with a length up to 33 meters. Currently there is a possibility of ordering more capacious rolling stock than those from years 2007-15 wagons $120 \mathrm{~N}$ Swing and 128N Jazz - thanks using four trucks it will be possible to 
extend the tram up to 33 meters and achieve a capacity of about 15-20\% higher i.e. $230-240$ of the 5 people $1 \mathrm{~m} 2$ on the floor and still - to reduce pressure per one tram axle. At the time of writing this article, the final decision on this matter has not been taken.

\section{Specific conditions}

The route has a number of specific points which require an individual approach to routing, technical solutions, functional solutions, traffic management, and protection of the environment.

The whole task of the project was divided into six sections (tasks), which will enable their almost independent proceedings for obtaining the environmental decision and further documentation; except for the section $\mathrm{D}$ and $\mathrm{E}$, which must be drawn together because of their nature run-down and one-sided connection to the existing tram system. Sectioning is shown in figure 3 .

In the section "A", i.e. from the KasprzakStreet to the area of West Railway Station, the route is run through the grounds Odolany and Czysty with a post-industrial nature, there is provided with intensive development activity in which an important role will play PKP. Odolany does not have a local development plan (it is in preparation), and Czyste LDP provides the tram a corridor, which fit in a difficult crossing with the central island Kasprzaka / Primate of the Millennium. An additional risk is the construction of tram before the road system, because the leveling and priming the area will surcharge this investment. An additional, and crucial point is in and of itself passage under the platforms of the West Railway Station - the location of bus stops and pedestrian accesses a significant optimization challenge.

In the Ochota district (section "B") some concerns may raise the construction of the tram by the area of the planned West Park. Currently, the recommended variant involves routing path tunnel under the area, although historically it was considered to run it around, along the road system. Here it is necessary to minimize interference to the planned for implementation park. The second green area, in which the route interferes in Ochota and Mokotów further (section "C") is a park Mokotów Field. The applicable local plan foresaw admittedly the reserve of land for the railway tracks (along the border of the park), but at the stage of design work it may become insufficient, and in and of itself location may be controversial for public at the stage of obtaining the environmental decision.

In Upper Mokotów (section "C"), without doubt the drivers protests will be raised because of narrowing the roadway Rakowiecka Street on its eastern section so as to allow the construction of a dedicated tramway line on its northern side. Such a solution, however, is stored in the current local plan and an alternative course - in the Batory Street - too far away from dense development of Mokotów, offers less attractive change to the subway, and additionally - may be even more difficult to correct solutions in the motor area of the team intersections between Union of Lublin square and Rakowiecka Street. 


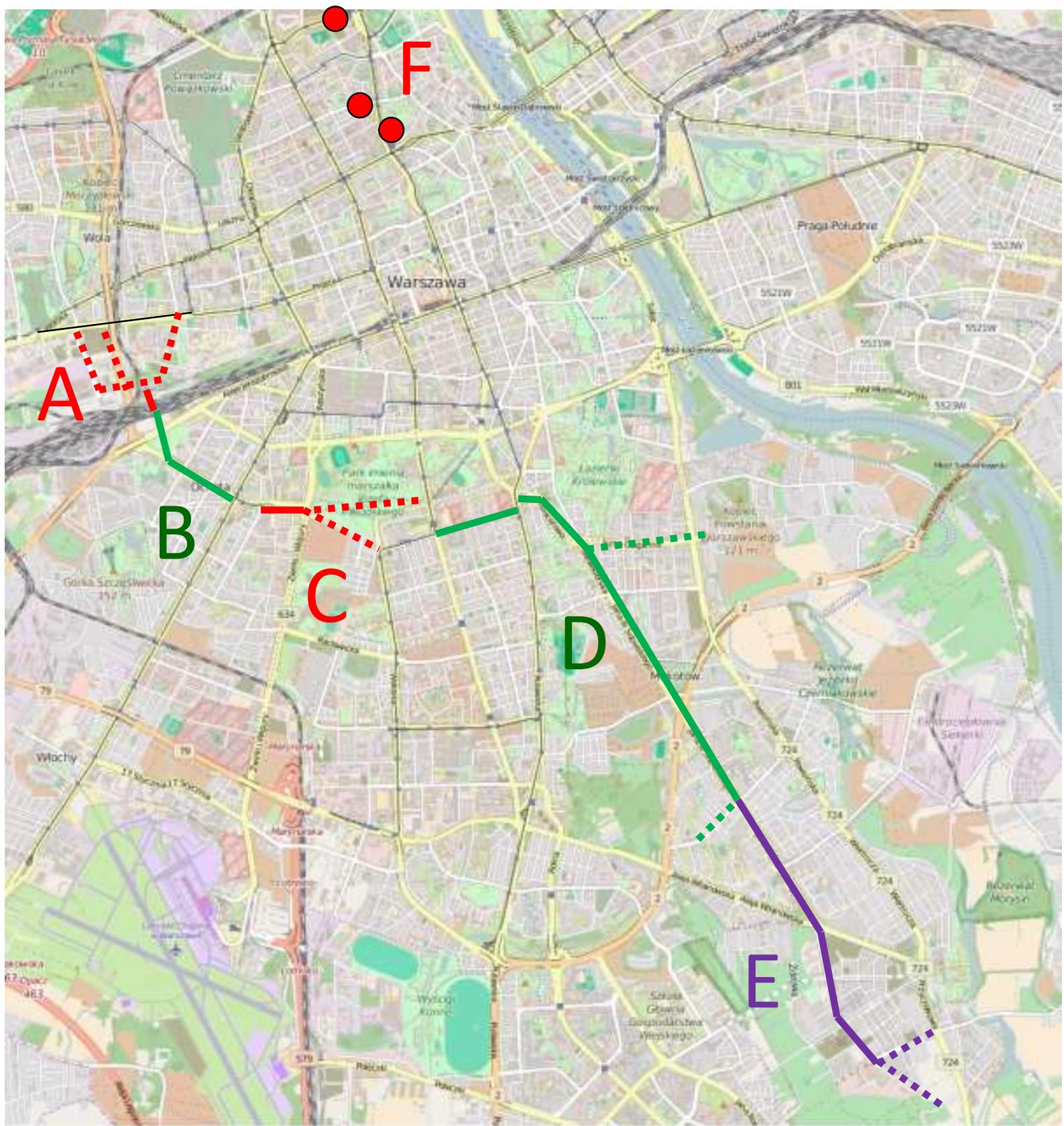

3. The division of the programmatically - spatial concept on sections. Variants and optional branch are indicated by the dashed line (ed. own work [4] and [2] ).

After the ramp, along Spacerowa Street the tram must squeeze through very burdened Belwederska Street. It has two three-strips roadways, but two lanes will have to be taken for the construction of track; due to expected to maintain strong communications bus on this stretch (associated primarily with support for the central part of the Trakt Królewski) it is assumed in this section to build a track for trams and buses. Not easy solution is crossings disband with Spacerowa and Dolna Streets, already overloaded, where trams and buses will be performed turning maneuvers and the latter - joining into the traffic on the trackway.

Although the corridor of Sobieski Street is quite broad, it contains a trap for the designer of tram route - a heat pipe, which position is variable in different sections of the street. Basically, on its ceiling the construction of tracks for a tram without a major refurbishment, is not possible. In addition, the corridor also supports the environment (Stegny, Sadyba) and constitutes a transit for residents of more distant settlements (Wilanow Wysoki, 
Miasteczko Wilanow) - hence we expect the conflicting demands of these groups of citizens in terms of stops density.

In the area of crossing with St. Boniface Street would be advisable to at least locate the comprising track allowing safe change of direction (and a short stop) bi-directional trams needed both during the construction phasing and for operating target (zoning line). Ideally, however,would be to place there the classical loop, e.g. using the bus loop "Stegny". Apart from the advantages of the comprising track also mean a passable route to north for unidirectional trams, valid not only in emergencies, but also for the growth of streams or desire referral to Lower Mokotów any of the existing tram lines operated essentially unidirectional trams; facilitate a possible vehicle rerouting of bus lines, for example line 501 running from loop Stegny through Sobieski Street to the Centre, if possible to replace the tram at all. The loop is in fact in the center of the building and bringing to it the tram significantly improve its availability. The disadvantage is, however, a potential social conflict - the construction of the tram in the St. Boniface Street was not previously planned.

Section " $F$ " includes variants of the end of the tram route in the city center - on the assumption of a line of buses going from Wilanów to Marszałkowska Street should end its run in the northern part of downtown i.e. north of route W-Z. With the set of use bidirectional rolling stock, there are different scenarios possible to solve this issue; analyzed locationsare indicated in Figure 3 above.

Last but far from the most banal, issue is to complete the route in the area of the Miasteczko Wilanow (section "E"). It is possible to lead both routes Branickiego Street to the Przyczółkowa Street (in the area of the planned shopping center), ending it near viaducts of projected route $S 2$ above Rzeczypospolitej Avenue, as well as stopping this stage even before Branickiego Street - where ends up ultimately built street and urban land lane underneath it acquired. For this problem will be crucial decisions of external entities to the Warsaw Trams: developer, general contractor for construction of the route S2, and - the General Directorate for National Roads and Motorways.

\section{Summary}

Construction of the tram route to Wilanów is the most important tram investment in Warsaw for many decades. With the connection to the Wola and branches of the Mokotów district the length of built in the framework of tram routes is about 18 kilometers (double track), which represents approx. $15 \%$ of the existing tram network. At the same time inventory train will increase by approx. $10 \%$, and the range of transport tasks - even more, because the route will be faster than the average of Warsaw. In terms of the EU project is included as the second important project: the construction of the first of more than 50 years of the new tram depot in Warsaw.

Mobilization is essential for these tasks implementation in required by EU funding period, - not only by the investor, but also on the municipal and administrators of utility networks.

\section{Source materials}

[1] Analizy funkcjonalno - ruchowych wariantów systemu transportowego Warszawy ze szczególnym uwzględnieniem komunikacji szynowej, CH2M HILL, Warszawa 2013.

[2] Specyfikacja istotnych warunków zamówienia na „Wykonanie wielobranżowej koncepcji budowy trasy tramwaju szybkiego od ul. Kasprzaka do Wilanowa w Warszawie wraz z materiałami dodatkowymi" - NZ-104-2015, Tramwaje Warszawskie Sp. z o.o., Warszawa 2015

[3] strona internetowa tramwar.republika.pl

[4] strona internetowa www.openstreetmap.org 
[5] Studium uwarunkowań i kierunków zagospodarowania przestrzennego m. st. Warszawy Uchwała Rady m.st. Warszawy nr LXXXII/2746/2006 z 10.10.2006 r. z późn. zm.

[6] Studium Wykonalności dla projektu: Budowa trasy tramwajowej do Warszawskiego Parku Techonologicznego, Faber Maunsell Polska Sp. z o.o. - Faber Maunsell Ltd., Warszawa 2007

[7] Studium Wykonalności dla projektu: Budowa trasy tramwajowej od dw. Zachodniego do Wilanowa, Faber Maunsell Ltd., Warszawa 2006

[8] Studium Wykonalności wraz z koncepcją przebiegu trasy tramwajowej dla projektu: „Budowa trasy tramwajowej od pętli Banacha do Wilanowa”, Faber Maunsell, Warszawa 2004

[9] Suchorzewski W., Brzeziński A. i in.: Analizy funkcjonalno - ruchowe wariantów systemu transportowego Warszawy ze szczególnym uwzględnieniem komunikacji szynowej, Politechnika Warszawska - Instytut Dróg i Mostów, Warszawa 1999. 